\title{
Botulinum Toxin for the Treatment of Neuropathic Pain
}

\author{
JungHyun Park ${ }^{1}$ and Hue Jung Park ${ }^{2, *}$ \\ 1 Department of Anaesthesiology \& Pain Medicine, Incheon St. Mary's Hospital, College of Medicine, \\ The Catholic University of Korea, Incheon 21431, Korea; happyjj@catholic.ac.kr \\ 2 Department of Anaesthesiology \& Pain Medicine, Seoul St. Mary's Hospital, College of Medicine, \\ The Catholic University of Korea, Seoul 06591, Korea \\ * Correspondence: huejung@catholic.ac.kr.; Tel.: +82-2258-2236 or +82-2258-6157
}

Academic Editor: Steve Peigneur

Received: 10 August 2017; Accepted: 21 August 2017; Published: 24 August 2017

\begin{abstract}
Botulinum toxin (BoNT) has been used as a treatment for excessive muscle stiffness, spasticity, and dystonia. BoNT for approximately 40 years, and has recently been used to treat various types of neuropathic pain. The mechanism by which BoNT acts on neuropathic pain involves inhibiting the release of inflammatory mediators and peripheral neurotransmitters from sensory nerves. Recent journals have demonstrated that BoNT is effective for neuropathic pain, such as postherpetic neuralgia, trigeminal neuralgia, and peripheral neuralgia. The purpose of this review is to summarize the experimental and clinical evidence of the mechanism by which BoNT acts on various types of neuropathic pain and describe why BoNT can be applied as treatment. The PubMed database was searched from 1988 to May 2017. Recent studies have demonstrated that BoNT injections are effective treatments for post-herpetic neuralgia, diabetic neuropathy, trigeminal neuralgia, and intractable neuropathic pain, such as poststroke pain and spinal cord injury.
\end{abstract}

Keywords: botulinum toxin; neuropathic pain; neuropathic pain treatment

\section{Introduction}

Botulinum toxin (BoNT) has been used for decades in the treatment of diseases, such as dystonia or seizures, and cosmetic treatments. BoNT is useful in conditions such as strabismus because it causes long lasting but reversible paralysis via the administration of small amounts locally [1,2]. As BoNT purification technology develops, the range of use of this drug has been expanded, and the number of Food and Drug Administration (FDA)-approval diseases has also increased. Common to these applications is the fact that BoNT is absorbed from the neuromuscular junction or parasympathetic axon terminal to the motor neuron terminal because the toxin is responsible for the release of acetylcholine. It is important to note that these effects are not systematically redistributed but only localized. Numerous reports suggest that local administration of BoNT has a significant effect on neuropathic pain.

For a long time, the analgesic effect of Botulinum toxin A (BoNT-A) was considered to be due to the effect of muscle relaxation [3-5]. However, recent studies using BoNT in neuropathic pain models have demonstrated that BoNT has an analgesic effect independent of muscle relaxation by demonstrating dissociation of the duration of muscle relaxation and duration of pain relief [6].

In this paper, we investigate the mechanism of BoNT in neuropathic pain by examining the effects of the drug for intractable neuropathic pains, such as postherpetic neuralgia, diabetic neuropathy, complex regional pain syndrome, trigeminal neuralgia, phantom limb pain, spinal cord injury-induced neuropathic pain, and central poststroke pain. 


\section{Structure of Botulinum Toxin}

BoNT is protein group produced by anaerobic bacteria called Clostridium botulinum, which has approximately 40 subtypes. However, seven serotypes are typically noted based on antigen specificity. Botulinum toxin A (BoNT-A) and B (BoNT-B) are the most commonly used drugs. Particularly, BoNT-A type has a molecular weight of approximately 900,000 . BoNT-A is a double chain protein. The light chain (LC) is active, whereas the heavy chain (HC) is not active. BoNT binds to the acceptor at the nerve end and enters the nerve ending by receptor-mediated endocytosis. LC binds to the exogenous protein involved in exocytosis and breaks down the peptide bond of the protein transporter to block exocytosis and acetylcholine secretion. The C-terminal receptor-binding domain, which constitutes the heavy chain of BoNT, binds to ganglioside receptors and specific proteins on the cell membrane. This binding induces endocytosis of HC-LC. In general, acetylcholine binding to the acetylcholine receptor of the motor endplate is necessary for muscle contraction. At this time, the acetylcholine exocytosis process is necessary in presynaptic membrane. The normal acetylcholine exocytosis process requires three proteins: the synaptosomal associated protein-25 $\mathrm{kDa}$ (SNAP-25), syntaxin, and the vesicle-associated membrane protein (VAMP)/synaptobrevin in the presynaptic membrane. These proteins are called soluble N-ethylmaleimide (SNARE) proteins. As a zinc-dependent endoprotease, the LC of BoNT cleaves intracellular SNARE. This cleavage interferes with SNARE-mediated protein transport and transmitter release, blocking muscle innervation at the neuromuscular junction and resulting in flaccid paralysis $[7,8]$. This effect of BoNT LC is dependent on the serotype, but it persists from days to months $[9,10]$.

BoNT-A and BoNT-B are effective in neuropathic pain. Mice can be treated with nerve ligation to induce mononeuropathy and cisplatin to induce polyneuropathy. BoNT-B improves allodynia and hyperalgesia [11]. A clinically reported case report demonstrates that BoNT-B improves pain and symptoms in complex regional pain syndrome (CRPS) patients with a lumbar sympathetic block [12].

\section{Mechanism of Action of Botulinum Toxin for Neuropathic Pain (Experimental Study)}

BoNT also reduces and alters neuropathic pain in several animal models via the following mechanisms. BoNT inhibits the secretion of pain mediators (substance $\mathrm{P}$, glutamate, and calcitonin gene related protein (CGRP)) from the nerve endings and dorsal root ganglions (DRG), reduces local inflammation around the nerve endings, deactivates the sodium channel, and exhibits axonal transport. We will review the various mechanisms by which BoNT reduces neuropathic pain (Figure 1).

\subsection{BoNT Inhibits the Release of Pain Mediators from the Peripheral Nerve Terminal, DRG, and Spinal Cord Neuron}

The effect of BoNT on the secretion of sensory neurotransmitters has been documented in several animal models. BoNT reduces normal CGRP release and capsaicin-induced DOA secretion and has additional effects on the TRPV1 pathway [13]. According to Meng et al., in a rat trigeminal ganglion sensory peptidergic neuron cell culture model, BoNT cleaves neuronal SNARE and blocks neurotransmitter secretion [14]. Durham et al. also reported a prophylactic advantage in migraine headaches via blocking the release of neuropeptides, such as CGRP from the trigeminal ganglion neuronal culture [15].

Fan et al. demonstrated that BoNT significantly reduces TRPV1 protein levels. Several studies demonstrated that TRPV1 plays a crucial role in arthritis pain, and this article examined the causal relationship between the antinociceptive effect of BoNT and the expression of TRPV1 in DRG of rats with arthritic pain. No significant changes in TRPV1 mRNA levels were observed via RT-PCR performed with different BoNT doses (1, 3, and $10 \mathrm{U})$; However, BoNT or TRPV1 protein levels were significantly decreased. This paper demonstrates the antinociceptive mechanism of BoNT by reducing TRPV1 expression by inhibiting plasma membrane trafficking after intra-articular administration [16]. 


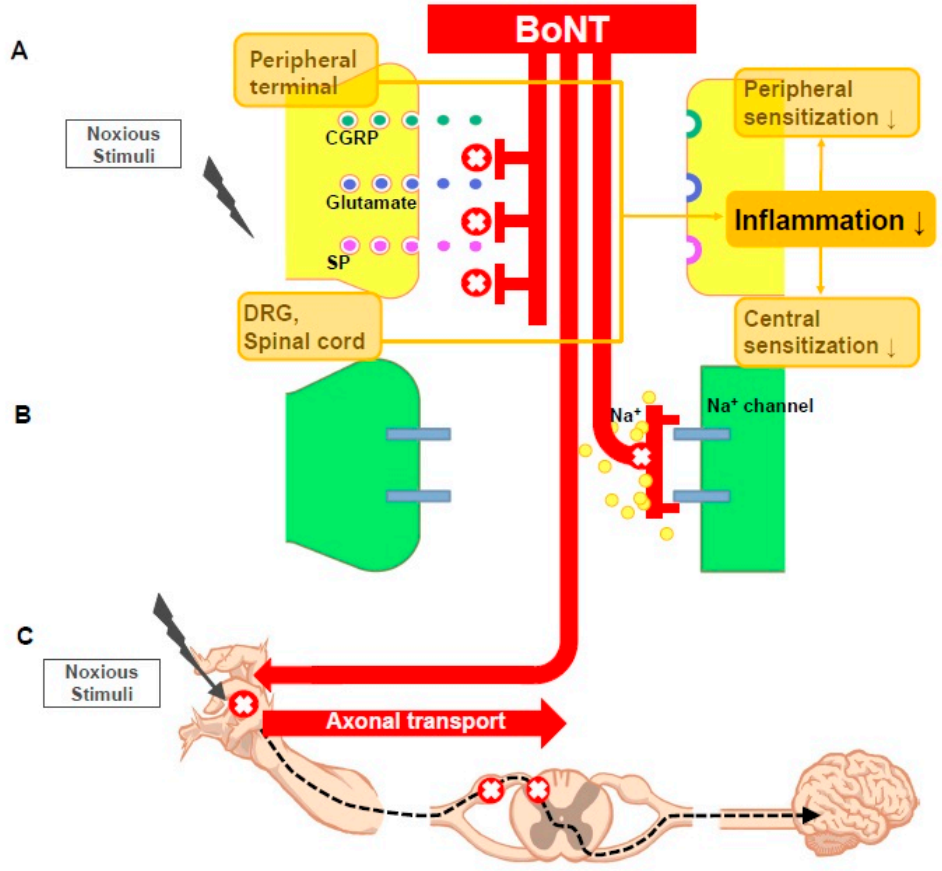

Figure 1. (A) Noxious stimuli cause inflammation through the release of neuropeptides and inflammatory mediators, which can cause peripheral sensitization. This action also occurs in DRG, dorsal horn of spinal cord and can lead to central sensitization. Botulinum toxin (BoNT) inhibits the release of pain mediators in peripheral nerve terminal, DRG, and spinal cord neuron, thereby reducing the inflammatory response and preventing the development of peripheral and central sensitization. Symbols; SP, substance P; CGRP, calcitonin gene related protein; DRG, dorsal root ganglion; (B) The hyperexcitability and spontaneous action potential mediated by the Na channel in peripheral sensory neuron contribute to the pathophysiology of neuropathic pain. BoNT can control neuropathic pain by blocking the Na channel; (C) Some of the BoNT appear to retrograde transport along the axons. SNAP-25 is cleaved in the dorsal horn of the spinal cord and central nuclei after a small amount of BoNT is administered to the periphery, thereby boosting the retrograde transport of BoNT.

\subsection{BoNT Reduces Inflammation}

Cyclophosphamide (CYP) was injected into the bladder of rats to induce CYP-induced cystitis, and HCL was injected into the bladder to induce acute injury. The bladder was harvested and compared with the Sham group. The cells were cultured in a solution containing BoNT to compare neurotransmitters. CGRP and substance $P$ were significantly increased in the acute injury group compared with the control group, and substance P was significantly increased in the CYP-induced cystitis group. After exposure to BoNT, neurotransmitter levels were significantly reduced. In this article, we found that BoNT has an anti-inflammatory effect on chronic inflammation and acute injury [17]. In a chronic arthritis dog model, intraarticular BoNT injections are effective for up to 12 weeks $[18,19]$. The anti-inflammatory effect of BoNT reduces the release of peripheral neurotransmitters and inflammatory mediators.

However, the effects are debated. Rojecky et al. injected carrageenan and capsaicin into the hindpaw of the rat, and rats were treated with BoNT five days before injection. No significant differences in edema and plasma protein extravasation were noted between the group injected with BoNT and the group without BoNT [20]. In addition, Sycha et al. reported that the BoNT group and the control group had no direct effect on acute, noninflammatory pain in the group treated with BoNT upon skin exposure to Ultraviolet B [21]. Chuang et al. measured cyclooxygenase-2 (COX-2) levels in the capsaicin-induced prostatitis model. COX-2 is a key enzyme that is an important mediator of inflammation and pain. COX-2 expression was induced as assessed by Western blotting 
or immunostaining. Inflammation was induced upon injection of capsaicin into the prostate of an adult male rat. Another group was pretreated with $20 \mathrm{U}$ BoNT one week before injection of capsaicin. The expression of COX-2 was reduced in spinal sensory and motor neurons and the prostate in the pretreatment group [22].

BoNT also decreases local inflammation around the nerve terminal. According to the report of Cui et al., BoNT was administered to the footpads in formalin-inflammatory pain model rats. The antinociceptive effect started $5 \mathrm{~h}$ after BoNT treatment and persisted for greater than 12 days. In addition, edema was reduced, but no localized muscle weakness was observed. Formalin-induced glutamate release was also significantly reduced. This finding demonstrates that local inflammation around the nerve endings is reduced in the absence of obvious muscle weakness [23].

\subsection{BoNT Deactivates Sodium Channels}

BoNT also deactivates the sodium channel. Na current stimulates numerous cellular functions, such as transmission, secretion, contraction, and sensation. BoNT-A changes the Na current of a neuronal excitable membrane, which is different from that of local anesthetics, tetrodotoxin, and antiepileptic drugs that completely control the $\mathrm{Na}$ current via a concentration-dependent manner [24].

\subsection{BoNT Exhibits Axonal Transport}

BoNT exhibits axonal transport function from the periphery to the CNS, and administering BoNT to the facial and trigeminal nerve causes SNAP-25 cleavage in the central nuclei. In addition, a small amount of BoNT was injected into the hind limb, confirming the cleavage of the SNAP-25 in the ventral horn and the dorsal horn of the ipsilateral spinal cord, thereby demonstrating the retrograde axonal transport function of BoNT [25]. In addition, the BoNT effect on both sides has been reported after injecting BoNT on one side [26-28]. In animal studies, the anti-nociceptive effect of BoNT was studied in paclitaxel-induced peripheral neuropathy. The withdrawal nociceptive reflex was reduced after paclitaxel injection into the hind paw of the rat. BoNT was injected into one side, but the analgesic effect was observed on both sides. Diffusion into blood circulation may affect the central nervous system, but the dose was too low to cause systemic side effects. BoNT is also too large to pass the BBB, so the theory that BoNT is transmitted from the periphery to the central nervous system through the axon is possible [28]. To prevent retrograde axonal transport, Rojecky et al. confirmed the antinociceptive effect of unilateral transport of the axonic transport blocker colchicine in the ipsilateral sciatic nerve [26], which also demonstrated the retrograde axonal transport of BoNT.

However, this notion is controversial. Tang et al. injected ${ }^{125} \mathrm{I}$-radiolabeled free BoNT into the gastrocnemius muscle of rats and rabbit eyelids and observed BoNT in various tissues at different time points. In both rabbits and rats, systemic effects were absent, and most of the toxins remained in the injection site. The authors concluded that most of the BoNT remained near the injection site and did not cause systemic toxicity [29].

Whether BoNT is transported retrograde from the injection site remains controversial. However, retrograde axonal transport has been demonstrated in numerous papers. Marinelli et al. analyzed the expression of cl-SNAP-25 from the nerve endings of the hind paw to the spinal cord after applying BoNT to the periphery. Immunostained cl-SNAP-25 was detected in all tissues. Additional experiments were performed to assess whether the growth state of Schwann cells interacts with BoNTs. As a result, BoNT regulated the proliferation of Schwann cells to inhibit acetylcholine release. This result demonstrates retrograde trafficking of BoNT [30]. 


\section{Clinical Study of Botulinum Toxin for Neuropathic Pain}

\subsection{Trigeminal Neuralgia}

A review of the efficacy of Botulinum toxin (BoNT) on trigeminal neuralgia (TN) has been reported in approximately 11 cases, including three RCT papers. This review includes the largest number of clinical trials for neuropathic pain for BoNT. In a randomized, double-blind, placebo-controlled study of 42 patients, Wu et al. performed a parallel design with intradermal or submucosal injection of $75 \mathrm{U}$ of BoNT-A in 22 patients. Twenty patients in the control group received $1.5 \mathrm{~mL}$ saline. In the BoNT group, $68.8 \%$ of patients had a visual analog scale (VAS) reduction of greater than $50 \%$. In the control group, a VAS reduction of greater than $50 \%$ was noted in $15 \%$ of the patients [31]. In addition, a randomized, double-blind, placebo-controlled study was performed in 84 adults with TN by Zhang et al. 28 control subjects were treated with saline, 27 with $25 \mathrm{U}$ BoNT-A, and 29 with $75 \mathrm{U}$ BoNT-A. The response rates in the $25 \mathrm{U}$ and $75 \mathrm{U}$ groups were $70.4 \%$ and $86.2 \%$, respectively, which were significantly different from the control group (32.1\%). However, no significant differences were noted between the two groups [32]. According to Zuniga et al., 20 patients received $50 \mathrm{U}$ of BoNT-A, and 16 controls received the same dose of saline. VAS was 4.9 vs. 6.63 at two months follow-up. No significant differences were noted between the two groups. At three months, there was a significant difference at 4.75 vs. 6.94 [33].

Prospective, open, and case series for trigeminal neuralgia are reported in three studies. According to Bohluli et al., $15 \mathrm{TN}$ patients were administered 50-100 U of BoNT-A in the trigger zone without any special injection mode. All patients reported a reduction in pain frequency and VAS score [34]. Zuniga et al. reported 12 trigeminal neuralgia patients who underwent subcutaneous injection in the trigger zone, and a reduction in VAS lasting greater than two months was noted in 10 patients [35]. Turk et al. also reported that injection of $50 \mathrm{U}$ BoNT-A at 1.5-2 cm depth around the zygomatic arch was performed in eight patients, and the incidence of pain and VAS were reduced in all patients [36]. The above papers are summarized in Table 1.

Table 1. Botulinum toxin for trigeminal neuralgia.

\begin{tabular}{|c|c|c|c|c|}
\hline Study Design & $\begin{array}{l}\text { Number of } \\
\text { Patients }\end{array}$ & $\begin{array}{c}\text { Method of Injection (Total } \\
\text { Volume) }\end{array}$ & Result & Reference \\
\hline $\begin{array}{l}\text { Randomized } \\
\text { double-blind, } \\
\text { placebo-controlled }\end{array}$ & 42 & $\begin{array}{l}\text { Intradermal, submucosal } \\
\text { (75 U/saline } 1.5 \mathrm{~mL})\end{array}$ & $\begin{array}{l}50 \% \text { VAS reduction } 68.8 \% \\
\text { (Botulinum toxin (BoNT) group) } \\
15 \% \text { (Control) }\end{array}$ & [31] \\
\hline $\begin{array}{l}\text { Randomized, } \\
\text { double-blind, } \\
\text { placebo-controlled }\end{array}$ & $\begin{array}{l}84 \text { (27 BoNT } 25 \mathrm{U}, \\
29 \text { BoNT } 75 \mathrm{U}, \\
28 \text { control })\end{array}$ & $\begin{array}{l}\text { Intradermal, submucosal } \\
\text { (25 U/75 U/saline } 1 \mathrm{~mL})\end{array}$ & $\begin{array}{l}\text { Visual analog scale (VAS) } \\
\text { reduction } 70.4 \%(25 \mathrm{U}) \text { vs. } \\
86.2 \%(75 \mathrm{U}) \text { vs. } 32.1 \% \text { (Control) }\end{array}$ & {$[32]$} \\
\hline $\begin{array}{l}\text { Randomized, } \\
\text { double-blind, } \\
\text { placebo-controlled }\end{array}$ & $\begin{array}{l}36 \text { (20 BoNT, } \\
16 \text { control) }\end{array}$ & $\begin{array}{l}\text { Intramuscular } \\
\text { (50 U/saline } 1 \mathrm{~mL})\end{array}$ & $\begin{array}{l}\text { VAS (BoNT vs. Control) } 4.9 \text { vs. } \\
6.63 \text { ( } 2 \text { months) } 4.75 \text { vs. } \\
6.94 \text { ( } 3 \text { months) }\end{array}$ & [33] \\
\hline $\begin{array}{l}\text { Prospective, open, } \\
\text { case series }\end{array}$ & 15 & $\begin{array}{l}\text { Injected at the trigger zones } \\
(50-100 \mathrm{U})\end{array}$ & $\begin{array}{l}\text { All patients improved frequency } \\
\text { and severity of pain attacks }\end{array}$ & {$[34]$} \\
\hline $\begin{array}{l}\text { Prospective, open, } \\
\text { case series }\end{array}$ & 12 & Subcutaneous (20-50 U) & $\begin{array}{l}\text { VAS reduced lasting more than } \\
2 \text { months in } 10 \text { patients. }\end{array}$ & [35] \\
\hline $\begin{array}{l}\text { Prospective, open, } \\
\text { case series }\end{array}$ & 8 & $\begin{array}{l}\text { Around zygomatic arch, } \\
1.5-2 \mathrm{~cm} \text { depth } \\
\text { (50 U per point, total } 100 \mathrm{U})\end{array}$ & $\begin{array}{l}\text { Incidence of pain and VAS were } \\
\text { reduced in all patients. }\end{array}$ & [36] \\
\hline
\end{tabular}

\subsection{Postherpetic Neuralgia}

Two BoNT RCTs for postherpetic neuralgia (PHN) have been reported. Xiao et al. performed a randomized, double-blind, placebo-controlled study of 60 patients with PHN. The following study groups were included: the BoNT group, $0.5 \%$ lidocaine group, and $0.9 \%$ saline group. These patients were treated $5 \mathrm{U} / \mathrm{mL}$ BoNT-A, $0.5 \%$ lidocaine and $0.9 \%$ saline in the affected dermatome, respectively. Follow-up was performed at one day, seven days, and three months after drug administration. The BoNT group exhibited significantly improved VAS and sleep quality compared with the other 
two groups [37]. In addition, Apalla et al. performed a randomized, double-blind, placebo-controlled study on 30 adults with PHN, and the affected sites were divided into a chessboard of 5 U BoNT-A per injection. Thirteen of the 15 patients had a VAS reduction of at least $50 \%$ lasting approximately 16 weeks and a significantly reduced the sleep score [38]. Previously, there were reports on the antinociceptic effect of BoNT. Liu et al. reported that the VAS decreased from 10 to 1 after BoNT-A injection into the lesion, and the effect persisted for 52 days [39]. Sotiriou et al. reported assessed a case series of three patients. The affected site was divided into a chessboard form using a total of $100 \mathrm{U}$ BoNT-A with $5 \mathrm{U}$ injected at each point. The VAS started to decrease in three days and continued to decrease for greater than two months [40]. These papers are summarized in Table 2.

Table 2. Botulinum toxin for postherpetic neuralgia.

\begin{tabular}{lllll}
\hline \multicolumn{1}{c}{ Study Design } & $\begin{array}{c}\text { Number of } \\
\text { Patients }\end{array}$ & $\begin{array}{c}\text { Method of Injection } \\
\text { (Total Volume) }\end{array}$ & Reference \\
\hline $\begin{array}{l}\text { Randomized, double-blind, } \\
\text { placebo-controlled }\end{array}$ & 60 & $\begin{array}{l}\text { Subcutaneous BoNT 5 U, } \\
\text { 0.5\% lidocaine, } \\
0.9 \% \text { saline per site }\end{array}$ & $\begin{array}{l}\text { Significantly VAS pain } \\
\text { score was decreased and } \\
\text { sleep time improved }\end{array}$ & [37] \\
\hline $\begin{array}{l}\text { Randomized, double-blind, } \\
\text { placebo-controlled }\end{array}$ & 30 & $\begin{array}{l}\text { Divided into chessboard } \\
\text { 5 U per site }\end{array}$ & $\begin{array}{l}50 \% \text { VAS reduction of } \\
13 \text { patients }\end{array}$ & {$[38]$} \\
\hline Case report & 1 & Fan pattern injection 100 U & $\begin{array}{l}\text { VAS decrease from 10 to 1 } \\
\text { Lasted for 52 days }\end{array}$ & {$[39]$} \\
\hline Case series & 3 & $\begin{array}{l}\text { Divided into chessboard } \\
\text { 5 U per site (100 U) }\end{array}$ & $\begin{array}{l}\text { VAS decrease and } \\
\text { continued to 2 months }\end{array}$ & [40] \\
\hline
\end{tabular}

\subsection{Post-Surgical Neuralgia}

Four reports on the efficacy of BoNT on post-surgical neuralgia, including RCT articles, have been published. RCT articles include post-herpetic neuralgia and post-traumatic neuralgia. According to Ranoux et al., 29 patients with focal painful neuropathy and mechanical allodynia were included in a randomized, double-blind, placebo-controlled study. Up to 20-190 U BoNT-A was injected into the pain site intradermally. The injections reduced VAS, burning sensation, and allodynic brush sensitivity and improved QOL [41]. Layeeque et al. also observed postoperative pain. In 48 breast cancer patients subject to mastectomy, 22 patients were treated with BoNT-A in the pectoralis major, serratus anterior, and rectus abdominis muscle, and 26 control group patients were not treated. The group treated with BoNT reported improved post-operative pain, and post-operative analgesic use was significantly reduced. In addition, the tissue expander was removed from one patient in the BoNT group and five patients in the control group. The BoNT group did not complain of any particular complications [42]. A case report described satisfactory results from subcutaneous injection of BoNT-A in a 67-year-old patient with post-thoracotomy pain for more than two years postoperatively. The pain site was divided into 1-square centimeter. Then, $2.5 \mathrm{U}$ of BoNT-A was injected into the middle, and $100 \mathrm{U}$ BoNT-A was administered in total. The patient reported improved pain after five days, and pain relief persisted for up to 12 weeks [43]. According to Rostami et al., eight cancer patients with persistent focal pain were treated with surgery or radiotherapy. BoNT-A was injected intramuscularly or subcutaneously into the localized pain area. All patients reported significant VAS improvement, and a significant improvement in QOL was also noted [44]. The above studies are described in Table 3. 
Table 3. Botulinum toxin for post-surgical neuralgia.

\begin{tabular}{|c|c|c|c|c|}
\hline Study Design & Number of Patients & $\begin{array}{c}\text { Method of Injection (Total } \\
\text { Volume) }\end{array}$ & Result & Reference \\
\hline $\begin{array}{l}\text { Randomized, } \\
\text { double-blind, } \\
\text { placebo-controlled }\end{array}$ & $\begin{array}{l}29 \text { (4 Postherpetic neuralgia, } \\
25 \text { Post-traumatic, } \\
\text { post-surgical neuropathy) }\end{array}$ & Intradermal (20-190 U) & $\begin{array}{l}\text { Decrease VAS, neuropathic } \\
\text { nature pain and improve in } \\
\text { quality of life }\end{array}$ & [41] \\
\hline $\begin{array}{l}\text { Prospective, } \\
\text { non-randomized, } \\
\text { placebo-controlled }\end{array}$ & 48 (22 BoNT, 26 control) & Intramuscular (100 U) & $\begin{array}{l}\text { Post-operative pain and } \\
\text { analgesic use was reduced }\end{array}$ & [42] \\
\hline Case report & 1 & $\begin{array}{l}\text { Subcutaneous Affected zone } \\
\text { was drawn with divisions of } \\
\text { approximately } 1 \mathrm{~cm}^{2}, \\
2.5 \mathrm{U} \text { per site }(100 \mathrm{U})\end{array}$ & $\begin{array}{l}\text { Improvement in pain was } \\
\text { about } 50 \% \text { as measured on } \\
\text { the VAS and persisted at } \\
12 \text { weeks }\end{array}$ & [43] \\
\hline Pilot, prospective & 8 & $\begin{array}{l}\text { Intramuscular, subcutaneous } \\
(100 \mathrm{U})\end{array}$ & $\begin{array}{l}\text { All patients had VAS } \\
\text { improvement }\end{array}$ & [44] \\
\hline
\end{tabular}

\subsection{Diabetic Neuropathy}

Two randomized, double-blind, placebo-controlled studies used BoNT for pain control of diabetic neuropathy (DN). In a study of $20 \mathrm{DN}$ patients, Yuan et al. reported that $4 \mathrm{U}$ of BoNT-A per site (total $50 \mathrm{U}$ ) was administered to the dorsum of foot, and $44 \%$ of patients had a clear reduction in VAS lasting three months and improved sleep quality [45]. Ghasemi et al. conducted a study similar to the previous paper, except that the BoNT dose was 8-10 U per site in $40 \mathrm{DN}$ patients. A decrease in neuropathic pain score (NPS) and Douleur Neuropathique 4 (DN4) scores were reported in that study [46]. A meta-analysis of these two articles concluded that DN has a significant association between BoNT and pain relief [47]. The above papers are described in Table 4.

Table 4. Botulinum toxin for diabetic neuropathy.

\begin{tabular}{lllll}
\hline \multicolumn{1}{c}{ Study Design } & $\begin{array}{c}\text { No. of } \\
\text { Patients }\end{array}$ & \multicolumn{1}{c}{$\begin{array}{c}\text { Method of Injection } \\
\text { (Total Volume) }\end{array}$} & Reference \\
\hline $\begin{array}{l}\text { Randomized, } \\
\text { double-blind, } \\
\text { placebo-controlled, } \\
\text { cross-over trial }\end{array}$ & 20 & $\begin{array}{l}\text { Intradermal 4 U per site at dorsum } \\
\text { of foot (50 U per each foot) }\end{array}$ & $\begin{array}{l}\text { Res\% of the BoNT group } \\
\text { experienced a reduction of } \\
\text { VAS within 3 months. }\end{array}$ & [45] \\
\hline $\begin{array}{l}\text { Randomized, } \\
\text { double-blind, } \\
\text { placebo-controlled }\end{array}$ & 40 & $\begin{array}{l}\text { Intradermal, dorsum of the foot, } \\
\text { in a grid distribution pattern, total } \\
12 \text { sites 8-10 U per site }\end{array}$ & $\begin{array}{l}\text { Decrease in neuropathic } \\
\text { pain score and Douleur } \\
\text { Neuropathique 4 }\end{array}$ & [46] \\
\hline
\end{tabular}

\subsection{Occipital Neuralgia}

Kapural et al. retrospectively analyzed six patients injected with 50 U BoNT-A in the occipital nerve and found that the VAS was significantly reduced. Five patients exhibited pain relief lasting greater than four weeks [48]. Taylor et al. reported that $100 \mathrm{U}$ of BoNT-A was administered to the occipital protuberance in the prospective, open, and case series. Improvement in sharp/shooting pain was noted, but no definite improvement in dull/aching pain was indicated [49]. Occipital neuralgia has been assessed in only two case series without an RCT article, so these studies are insufficient to prove the effectiveness of BoNT. The above papers are also described in Table 5. 
Table 5. Botulinum toxin for occipital neuralgia.

\begin{tabular}{lllll}
\hline \multicolumn{1}{c}{ Study Design } & $\begin{array}{c}\text { No. of } \\
\text { Patients }\end{array}$ & \multicolumn{1}{c}{$\begin{array}{c}\text { Method of Injection } \\
\text { (Total Volume) }\end{array}$} & Reference \\
\hline Case series & 6 & $\begin{array}{l}\text { Occipital nerve block 50 U } \\
\text { for each block (100 U) }\end{array}$ & $\begin{array}{l}\text { Significant VAS reduction and } \\
\text { pain relief lasting >4 weeks }\end{array}$ & [48] \\
\hline $\begin{array}{l}\text { Prospective, open, } \\
\text { case series }\end{array}$ & 6 & $\begin{array}{l}\text { Greater and lesser occipital } \\
\text { nerve block (100 U) }\end{array}$ & $\begin{array}{l}\text { Improvement in sharp/shooting } \\
\text { pain, no definite improvement } \\
\text { in dull/aching pain }\end{array}$ & [49] \\
\hline
\end{tabular}

\subsection{Carpal Tunnel Syndrome}

Breuer et al. conducted a randomized, double-blind, placebo-controlled study of 20 patients. In this study, 2,500 U of BoNT-B or saline was injected into hypothena muscle and tentorium associated with carpal tunnel. Tingling sensation, pain, and pain related to improved sleep were noted, but there was no significant difference compared with the control group [50]. In a prospective, open, pilot study of five patients, a total of $30 \mathrm{U}$ of BoNT-A was injected intracarpally. Of the five patients, three reported insignificant pain relief, and none had electrophysiological changes [51]. These results suggest that the use of BoNT in carpal tunnel syndrome is not effective. These papers are described in Table 6.

Table 6. Botulinum toxin for carpal tunnel syndrome.

\begin{tabular}{lllll}
\hline \multicolumn{1}{c}{ Study Design } & $\begin{array}{c}\text { No. of } \\
\text { Patients }\end{array}$ & $\begin{array}{c}\text { Method of Injection } \\
\text { (Total Volume) }\end{array}$ & Reference \\
\hline $\begin{array}{l}\text { Randomized, } \\
\text { double-blind, } \\
\text { placebo-controlled }\end{array}$ & 20 & $\begin{array}{l}\text { Intramuscular, hypothena } \\
\text { muscle, tentorium (2500 U) }\end{array}$ & $\begin{array}{l}\text { No significant difference } \\
\text { compared to the control group }\end{array}$ & [50] \\
\hline $\begin{array}{l}\text { Prospective, } \\
\text { open, pilot }\end{array}$ & 5 & $\begin{array}{l}\text { Intracapal 30 U for each } \\
\text { carpal tunnel (60 U) }\end{array}$ & $\begin{array}{l}\text { Three patients insignificant } \\
\text { reduced pain, none had } \\
\text { electrophysiological change. }\end{array}$ \\
\hline
\end{tabular}

\subsection{CRPS}

Safarpour et al. reported that two patients with CRPS had a reduction of CRPS and myofascial pain with the intramuscular administration of $20 \mathrm{U}$ BoNT-A per site and trigger point injection [52]. They also performed randomized, prospective, double-blind, placebo-controlled, open-label extension studies of BoNT in CRPS patients. Fourteen patients with CRPS were divided into the BoNT group $(n=8)$ and control group $(n=6)$. A total of $40-200 \mathrm{U}$ (5 U per point) BoNT was administered to the affected area with allodynia. No difference was found between the interventional group and the placebo group, and this study was terminated early due to the intolerance of BoNT [53]. In another study, lumbar sympathetic block was performed in a randomized, double-blind, placebo-controlled crossover study. Patients received standard LSGB on one side, and $10 \mathrm{~mL}$ of $0.5 \%$ bupivacaine was used. The same patient was injected with a crossover (another side) injection of $75 \mathrm{U}$ BoNT-A in $10 \mathrm{~mL}$ of $0.5 \%$ bupivacaine. The control group has a median of 10 days, whereas the BoNT group has a median of 71 days [54]. In a case series published by Choi et al., two patients who experienced short-term effects on the lumbar sympathetic block were injected with $5000 \mathrm{U}$ of BoNT-B in $0.25 \%$ levobupivacaine with a lumbar sympathetic block. VAS, allodynia, edema, coldness, and analgesic drug usage were reduced [12]. In a prospective, open case series of 11 patients with CRPS symptoms in upper limb girdle muscles, a total of $300 \mathrm{U}$ of BoNT-A was administered to the pain-related muscles at 25-50 U. All patients exhibited improved VAS, allodynia, hyperalgesia, and skin color after 6-12 weeks [55]. In a retrospective, uncontrolled, unblended study of 37 patients, as a result of administering a total of $100 \mathrm{U}$ of BoNT-A (10-20 U per pain site), $97 \%$ of patients reported pain reduction, and the average pain score decreased by $43 \%$ [56]. Except for one negative study, positive results have been published. 
However, these studies include a low class papers, and the effect of BoNT in CRPS patients has not been proven. These papers are summarized in Table 7.

Table 7. Botulinum toxin for complex regional pain syndrome (CRPS).

\begin{tabular}{|c|c|c|c|c|}
\hline Study Design & $\begin{array}{l}\text { Number of } \\
\text { Patients }\end{array}$ & $\begin{array}{l}\text { Method of Injection } \\
\text { (Total Volume) }\end{array}$ & Result & Reference \\
\hline Case series & 2 & $\begin{array}{l}\text { Intramuscular Trigger } \\
\text { point } 20 \mathrm{U} \text { per site }\end{array}$ & $\begin{array}{l}\text { Reduction of CRPS pain and } \\
\text { myofascial pain }\end{array}$ & [52] \\
\hline $\begin{array}{l}\text { Randomized, } \\
\text { prospective, } \\
\text { double-blind, } \\
\text { placebo-controlled, } \\
\text { and open-label extension }\end{array}$ & $\begin{array}{l}14 \text { (8 BoNT group, } \\
6 \text { control group) }\end{array}$ & $\begin{array}{l}\text { Intradermal, subcutaneous } \\
\text { Allodynia area } 5 \text { U per site } \\
(40-200 \mathrm{U})\end{array}$ & $\begin{array}{l}\text { No difference between BoNT } \\
\text { group and placebo group, } \\
\text { terminated study early. }\end{array}$ & [53] \\
\hline $\begin{array}{l}\text { Randomized, } \\
\text { double-blind, } \\
\text { placebo-controlled } \\
\text { crossover }\end{array}$ & 9 (18 cases) & $\begin{array}{l}\text { Lumbar sympathetic block } \\
75 \text { U BoNT }+0.5 \% \\
\text { bupivacaine } / 0.5 \% \\
\text { bupivacaine }\end{array}$ & $\begin{array}{l}\text { Longer duration of pain } \\
\text { reduction (BoNT vs. } \\
\text { control/71 days vs. } 10 \text { days) }\end{array}$ & [54] \\
\hline Case series & 2 & $\begin{array}{l}\text { Lumbar sympathetic block } \\
5000 \text { U BoNT-B }+0.25 \% \\
\text { levobupivacaine }\end{array}$ & $\begin{array}{l}\text { VAS and CRPS symptoms } \\
\text { were reduced. }\end{array}$ & [12] \\
\hline $\begin{array}{l}\text { Prospective, } \\
\text { open case series }\end{array}$ & 11 & $\begin{array}{l}\text { Affected site, } \\
\text { 25-50 U per site (300 U) }\end{array}$ & $\begin{array}{l}\text { All patients had improved VAS, } \\
\text { allodynia, hyperalgesia, and } \\
\text { skin color after } 6 \text { to } 12 \text { weeks }\end{array}$ & [55] \\
\hline $\begin{array}{l}\text { Retrospective, } \\
\text { uncontrolled, unblended }\end{array}$ & 37 & $\begin{array}{l}\text { Affected site, } \\
\text { 10-20 U per site (100 U) }\end{array}$ & $\begin{array}{l}\text { The } 97 \% \text { patients reduced pain. } \\
\text { (average pain reduction of } 43 \% \text { ) }\end{array}$ & [56] \\
\hline
\end{tabular}

\subsection{Phantom Limb Pain}

In a prospective, randomized, double-blind pilot study, 14 patients with phantom limb pain were treated with $50 \mathrm{U}$ per site for a total of 250-300 U BoNT-A. In addition, a lidocaine and depomedrol mixture was administered at the focal tender point. VAS was assessed monthly in patients before and six months after treatment. Both groups reported improved pain. The BoNT group had an advantage over pain control during the 3-6 months, but phantom limb pain was not completely alleviated [57]. There is a case report in which the effect of BoNT was effective in reducing phantom limb pain for greater than 12 months. In total, $25 \mathrm{U}$ of BoNT-A was injected into the trigger point of the stump at four sites, and the patient was able to reduce the pain medication given that the pain was significantly eliminated [58]. The effect of BoNT on phantom limb pain cannot be verified because only low-grade studies on phantom limb pain have been reported. The above papers are also listed in Table 8.

Table 8. Botulinum toxin for phantom limb pain.

\begin{tabular}{llll}
\hline \multicolumn{1}{c}{ Study Design } & $\begin{array}{c}\text { No. of } \\
\text { Patients }\end{array}$ & \multicolumn{1}{c}{ Method of Injection (Total Volume) } & \multicolumn{1}{c}{ Result } \\
\hline $\begin{array}{l}\text { Prospective, } \\
\text { randomized, } \\
\text { double-blind, pilot }\end{array}$ & 14 & $\begin{array}{l}\text { Intramuscular/cutaneous/subcutaneous / } \\
\text { neuroma (EMG guidance) 50 U per site } \\
(250-300 \mathrm{U})\end{array}$ & $\begin{array}{l}\text { Both groups improved pain and } \\
\text { BoNT group had an advantage over } \\
\text { pain control during 3-6 months but } \\
\text { could not completely change } \\
\text { phantom limb pain. }\end{array}$ \\
\hline [57] & $\begin{array}{l}\text { Phantom pain, pain medication could } \\
\text { be reduced, the gait became more } \\
\text { stable and the artificial limb was } \\
\text { better tolerated. }\end{array}$ \\
\hline
\end{tabular}

\subsection{Spinal Cord Injury-Induced Neuropathic Pain}

In a study of 40 patients with spinal cord injury-induced neuropathic pain, a randomized, double-blind, placebo-controlled design was used. In the BoNT group, 200 U BoNT-A was divided into 40 sites, and $4 \mathrm{~mL}$ of saline was administered to the control group in a similar manner. Pain intensities were assessed using VAS, the Korean version of the short-form McGill Pain Questionnaire 
(SF-MPQ), and the Korean version of the World Health Organization Quality of Life (WHOQOL-BREF) questionnaire. The same procedure was performed at baseline and four and eight weeks. The BoNT group exhibited a statistically significant decrease in VAS at four and eight weeks compared with the placebo group, and SF-MPQ was also significantly reduced compared with the placebo group. However, there was no significant difference between the control group and the BoNT group in the Korean version of the WHOQOL-BREF, which assesses physical health, psychological social relationship, and environmental domains [59]. A similar paper was published in 2017, and a randomized, double-blind, placebo-controlled study was performed in 44 patients with spinal cord injury-induced neuropathic pain. The BoNT group received $200 \mathrm{U}$ of BoNT-A at the pain site, and the control group received the same amount of saline at the pain site. Unlike the above paper, patients received the same treatment once daily for eight weeks. The primary outcome of pain was measured on a VAS scale, and the secondary outcome was measured by the SF-MPQ and the WHOQOL-BREF questionnaire. At four and eight weeks, both primary and secondary outcomes were measured and evaluated. No adverse effect was noted in both groups. VAS and SF-MPQ were significantly decreased in the BoNT group compared with placebo group at four and eight weeks, respectively. The difference from the above paper is that the WHOQOL-BREF also exhibited a statistically significant decrease compared with the placebo group [60].

In addition, there have been several case reports of neuropathic pain associated with spinal cord injury. Jabbari et al. reported that two patients who had burning pain and allodynia after spinal cord injury injected with $5 \mathrm{U}$ of BoNT-A at 16-20 sites in the pain site maintained significant VAS reduction for greater than three months [61]. Han et al. mentioned that $20 \mathrm{U}$ of BoNT-A was injected into 10 painful areas in patients with spinal cord injuries, and VAS was decreased from 96 to 23 [62]. The use of BoNT for spinal cord injury is considered to be effective based on a statistically significant RCT journal report. These papers are listed in Table 9.

Table 9. Botulinum toxin for spinal cord injury-induced neuropathic pain.

\begin{tabular}{lllll}
\hline \multicolumn{1}{c}{ Study Design } & $\begin{array}{l}\text { Number of } \\
\text { Patients }\end{array}$ & $\begin{array}{c}\text { Method of Injection } \\
\text { (Total Volume) }\end{array}$ & \multicolumn{1}{c}{ Result } & Reference \\
\hline $\begin{array}{l}\text { Randomized, double-blind, } \\
\text { placebo-controlled }\end{array}$ & 40 & Subcutaneous (200 U) & $\begin{array}{l}\text { Significantly VAS was } \\
\text { decreased at 4 and 8 weeks. }\end{array}$ & [59] \\
\hline $\begin{array}{l}\text { Randomized, double-blind, } \\
\text { placebo-controlled }\end{array}$ & 44 & $\begin{array}{l}\text { Subcutaneous (200 U) } \\
\text { Once daily for 8 weeks }\end{array}$ & $\begin{array}{l}\text { Significantly VAS was } \\
\text { decreased at 4 and 8 weeks. }\end{array}$ & {$[60]$} \\
\hline Case & 2 & $\begin{array}{l}\text { Subcutaneous 5 U of BoNT } \\
\text { at 16-20 sites }\end{array}$ & $\begin{array}{l}\text { Significant VAS reduction } \\
\text { for more than 3 months }\end{array}$ & [61] \\
\hline Case & 1 & $\begin{array}{l}\text { Subcutaneous 20 U of } \\
\text { BoNT at 10 sites }\end{array}$ & VAS decreased from 96 to 23. & [62] \\
\hline
\end{tabular}

\subsection{Central Poststroke Pain}

Poststroke patients often use BoNT due to poststroke spasticity. However, some recent reports have reported that BoNT is used for central poststroke pain control. Shippen et al. injected BoNT in patients with elbow flexor spasticity with central poststroke pain. The patients had severe neuropathic pain at the site of the spasticity and received $100 \mathrm{U}$ BoNT-A of Biceps Brachii, $75 \mathrm{U}$ Brachialis and $25 \mathrm{U}$ Brachioradialis. After the second day, the pain was reduced, and the spasticity was improved one week after administration. The patients repeat BoNT every three months to control pain [63]. Barbosa et al. also published a case report in which an analgesic effect was obtained using BoNT-A in patients with central poststroke pain. In two patients with stroke, injection of BoNT-A $200 \mathrm{U}$ into the affected area under EMG guidance resulted in a decrease in NRS after a 3-month follow-up [64]. A randomized, double-blind, placebo-controlled trial of 273 patients with poststroke spasticity was performed. In total, $74.3 \%$ of the patients had stroke-related pain, and $47.3 \%$ were suffering from greater than NRS 4. Patients were divided into two groups: BoNT-A and standard care vs. placebo and standard care. The degree of pain was compared 12 weeks from the baseline, and the BoNT group 
reported significantly less pain compared with the placebo group. The reduction in pain persisted for up to 52 weeks [65]. This is the first RCT assessing the control of neuropathic pain with BoNT in patients with poststroke spasticity. Therefore, BoNT may be effective in patients with central poststroke pain. The above papers are summarized in Table 10.

Table 10. Botulinum toxin for central poststroke pain.

\begin{tabular}{lllll}
\hline \multicolumn{1}{c}{ Study Design } & \multicolumn{1}{c}{$\begin{array}{c}\text { Number of } \\
\text { Patients }\end{array}$} & \multicolumn{1}{c}{$\begin{array}{c}\text { Method of Injection } \\
\text { (Total Volume) }\end{array}$} & Result & Reference \\
\hline Case & 1 & $\begin{array}{l}\text { Intramuscular Biceps Brachii } \\
\text { 100 U, Brachialis 75 U and } \\
\text { Brachioradialis 25 U }\end{array}$ & $\begin{array}{l}\text { Pain was reduced after } \\
\text { 2 days, spasticity was } \\
\text { improved after 1 week. }\end{array}$ & {$[63]$} \\
\hline Case & 2 & $\begin{array}{l}\text { Intramuscular Affected muscle } \\
(200 \text { U) }\end{array}$ & $\begin{array}{l}\text { NRS reduction for more } \\
\text { than 3 months }\end{array}$ & {$[64]$} \\
\hline $\begin{array}{l}\text { Randomized, } \\
\text { double-blind, } \\
\text { placebo-controlled }\end{array}$ & $273(139$ BoNT, & $\begin{array}{l}\text { Intramuscular Dosing was } \\
\text { determined by investigator, } \\
\text { second injection was performed } \\
\text { with an open label and at least } \\
\text { 12 weeks after the first injection }\end{array}$ & $\begin{array}{l}\text { Significantly VAS was } \\
\text { decreased at 12 weeks and } \\
\text { reductions in pain were } \\
\text { sustained through Week 52. }\end{array}$ & [65] \\
\hline
\end{tabular}

\section{Adverse Effects}

BoNT-A has minimal irreversible medical adverse effect. Regarding the use of BoNT in cervical dystonia, side effects, including neck muscle weakness, dysphagia, pain during swallowing, and flu-like symptoms, are rarely reported. The use of BoNT in blepharospasm and cerebral palsy is associated with unilateral or bilateral ptosis, hematoma, and lower limb weakness and pain. When BoNT is used in neuropathic pain, relatively minor complications, such as antibody formation and immune-related complications, are reported when a small amount of BoNT-A enters the circulatory system [66]. BoNT-B can also be used to obtain effective results when neutralizing antibodies are present in BoNT-A, and the effect is reduced. $[67,68]$.

\section{Conclusions}

Before beginning BoNT therapy, patients with neuropathic pain require a careful assessment of functional limitations, goals, and expected outcomes. The guidelines of the American Academy of Neurology recommend the use of BoNT-A in neuropathic pain as follows. In postherpetic neuralgia, trigeminal neuralgia, and spinal cord injury-induced neuropathic pain, BoNT is effective (Level A) and BoNT is probably effective in post-surgical neuralgia, diabetic neuropathy, and central poststroke pain (Level B). In neuropathic pain, such as occipital neuralgia, CRPS, and phantom limb pain, a large and well-designed blinded and randomized controlled trial is needed to evaluate the effect of BoNT. The route of administration of BoNT is different for each article. There are no clinical guidelines for administration of BoNT for neuropathic pain. Most treatments are subcutaneous or intradermal, and BoNT is also injected intramuscularly or into the surrounding tissues. In some papers, BoNT is injected into the skin as a chessboard. In other studies, BoNT is directly injected into the nerve. In particular, the development of ultrasound technology can accurately inject drugs near the nerve, and BoNT injection near the nerve is emerging as an alternative method [69].

There is a need for comparative studies on whether these methods are effective and safe or which methods are more effective than others. In addition, studies should be carried out to compare the minimum doses that are effective. Large, well-designed clinical trials are needed to address these problems.

Conflicts of Interest: The authors declare no conflict of interest. 


\section{References}

1. Thenganatt, M.A.; Fahn, S. Botulinum toxin for the treatment of movement disorders. Curr. Neurol. Neurosci. Rep. 2012, 12, 399-409. [CrossRef] [PubMed]

2. Pellizzari, R.; Rossetto, O.; Schiavo, G.; Montecucco, C. Tetanus and botulinum neurotoxins: Mechanism of action and therapeutic uses. Philos. Trans. R. Soc. Lond. B Biol. Sci. 1999, 354, 259-268. [CrossRef] [PubMed]

3. Porta, M. A comparative trial of botulinum toxin type A and methylprednisolone for the treatment of myofascial pain syndrome and pain from chronic muscle spasm. Pain 2000, 85, 101-105. [CrossRef]

4. Foster, L.; Clapp, L.; Erickson, M.; Jabbari, B. Botulinum toxin A and chronic low back pain. A randomized, double-blind study. Neurology 2001, 56, 1290-1293. [CrossRef] [PubMed]

5. Fishman, L.M.; Anderson, C.; Rosner, B. BOTOX and physical therapy in the treatment of piriformis syndrome. Am. J. Phys. Med. Rehabil. 2002, 81, 936-942. [CrossRef] [PubMed]

6. Park, H.J.; Lee, Y.; Lee, J.; Park, C.; Moon, D.E. The effects of botulinum toxin A on mechanical and cold allodynia in a rat model of neuropathic pain. Can. J. Anaesth. 2006, 53, 470-477. [CrossRef] [PubMed]

7. Johnson, E.A.; Montecucco, C. BOTULISM. In Handbook of Clinical Neurology; Andrew, G.E., Ed.; Elsevier: Amsterdam, The Netherlands, 2008; pp. 333-368.

8. Montecucco, C.; Schiavo, G. Mechanism of action of tetanus and botulinum neurotoxins. Mol. Microbiol. 1994, 13, 1-8. [CrossRef] [PubMed]

9. Pantano, S.; Montecucco, C. The blockade of the neurotransmitter release apparatus by botulinum neurotoxins. Cell. Mol. Life Sci. 2014, 71, 793-811. [CrossRef] [PubMed]

10. Whitemarsh, R.C.; Tepp, W.H.; Johnson, E.A.; Pellett, S. Persistence of botulinum neurotoxin a subtypes 1-5 in primary rat spinal cord cells. PLoS ONE 2014, 9, e90252. [CrossRef] [PubMed]

11. Park, H.J.; Marino, M.J.; Rondon, E.S.; Xu, Q.; Yaksh, T.L. The effects of intraplantar and intrathecal botulinum toxin type B on tactile allodynia in mono and polyneuropathy in the mouse. Anesth. Analg. 2015, 121, 229-238. [CrossRef] [PubMed]

12. Choi, E.; Cho, C.W.; Kim, H.Y.; Lee, P.B.; Nahm, F.S. Lumbar sympathetic block with botulinum toxin type B for complex regional pain syndrome: A case study. Pain Phys. 2015, 18, 911-916.

13. Kharatmal, S.B.; Singh, J.N.; Sharma, S.S. Voltage-gated sodium channels as therapeutic targets for treatment of painful diabetic neuropathy. Mini Rev. Med. Chem. 2015, 15, 1134-1147. [CrossRef] [PubMed]

14. Meng, J.; Wang, J.; Lawrence, G.; Dolly, J.O. Synaptobrevin I mediates exocytosis of cgrp from sensory neurons and inhibition by botulinum toxins reflects their anti-nociceptive potential. J. Cell Sci. 2007, 120, 2864-2874. [CrossRef] [PubMed]

15. Durham, P.L.; Cady, R. Insights into the mechanism of onabotulinumtoxinA in chronic migraine. Headache 2011, 51, 1573-1577. [CrossRef] [PubMed]

16. Fan, C.; Chu, X.; Wang, L.; Shi, H.; Li, T. Botulinum toxin type A reduces TRPV1 expression in the dorsal root ganglion in rats with adjuvant-arthritis pain. Toxicon 2017, 133, 116-122. [CrossRef] [PubMed]

17. Lucioni, A.; Bales, G.T.; Lotan, T.L.; McGehee, D.S.; Cook, S.P.; Rapp, D.E. Botulinum toxin type A inhibits sensory neuropeptide release in rat bladder models of acute injury and chronic inflammation. BJU Int. 2008, 101, 366-370. [CrossRef] [PubMed]

18. Heikkila, H.M.; Hielm-Bjorkman, A.K.; Morelius, M.; Larsen, S.; Honkavaara, J.; Innes, J.F.; Laitinen-Vapaavuori, O.M. Intra-articular botulinum toxin A for the treatment of osteoarthritic joint pain in dogs: A randomized, double-blinded, placebo-controlled clinical trial. Vet. J. 2014, 200, 162-169. [CrossRef] [PubMed]

19. Hadley, H.S.; Wheeler, J.L.; Petersen, S.W. Effects of intra-articular botulinum toxin type A (Botox ${ }^{\circledR}$ ) in dogs with chronic osteoarthritis. Vet. Comp. Orthop. Traumatol. 2010, 23, 254-258. [CrossRef] [PubMed]

20. Bach-Rojecky, L.; Dominis, M.; Lackovic, Z. Lack of anti-inflammatory effects of botulinum toxin A in experimental models of inflammation. Fundam. Clin. Pharmacol. 2008, 22, 503-509. [CrossRef] [PubMed]

21. Sycha, T.; Samal, D.; Chizh, B.; Lehr, S.; Gustorff, B.; Schnider, P.; Auff, E. A lack of antinociceptive or antiinflammatory effect of botulinum toxin A in an inflammatory human pain model. Anesth. Analg. 2006, 102, 509-516. [CrossRef] [PubMed]

22. Chuang, Y.C.; Yoshimura, N.; Huang, C.C.; Wu, M.; Chiang, P.H.; Chancellor, M.B. Intraprostatic botulinum toxin A injection inhibits cyclooxygenase-2 expression and suppresses prostatic pain on capsaicin induced prostatitis model in rat. J. Urol. 2008, 180, 742-748. [CrossRef] [PubMed] 
23. Cui, M.; Khanijou, S.; Rubino, J.; Aoki, K.R. Subcutaneous administration of botulinum toxin A reduces formalin-induced pain. Pain 2004, 107, 125-133. [CrossRef] [PubMed]

24. Shin, M.C.; Wakita, M.; Xie, D.J. Inhibition of membrane Na+ channels by A type botulinum toxin at femtomolar concentrations in central and peripheral neurons. J. Pharmacol. Sci. 2012, 118, 33-42. [CrossRef] [PubMed]

25. Matak, I.; Riederer, P.; Lacković, Z. Botulinum toxin's axonal transport from periphery to the spinal cord. Neurochem. Int. 2012, 61, 236-239. [CrossRef] [PubMed]

26. Bach-Rojecky, L.; Lackovic, Z. Central origin of the antinociceptive action of botulinum toxin type A. Parmacol. Biochem. Behav. 2009, 94, 234-238. [CrossRef] [PubMed]

27. Bach-Rojecky, L.; Salkovic-Petrisic, M.; Lackovic, Z. Botulinum toxin type A reduces pain supersensitivity in experimental diabetic neuropathy: Bilateral effects after unilateral injection. Eur. J. Pharmacol. 2010, 633, 10-14. [CrossRef] [PubMed]

28. Favre-Guilmard, C.; Auguet, M.; Chabrier, P.E. Different antinociceptive effects of botulinum toxin type A in inflammatory and peripheral polyneuropathic rat models. Eur. J. Pharmacol. 2009, 617, 48-53. [CrossRef] [PubMed]

29. Tang-Liu, D.D.; Aoki, K.R.; Dolly, J.O.; de Paiva, A.; Houchen, T.L.; Chasseaud, L.F.; Webber, C. Intramuscular injection of 125I-botulinum neurotoxin-complex versus 125I-botulinum-free neurotoxin: Time course of tissue distribution. Toxicon 2003, 42, 461-469. [CrossRef]

30. Marinelli, S.; Vacca, V.; Ricordy, R.; Uggenti, C.; Tata, A.M.; Luvisetto, S.; Pavone, F. The analgesic effect on neuropathic pain of retrogradely transported botulinumneurotoxin A involves Schwann cells and astrocytes. PLoS ONE 2012, 7, e47977. [CrossRef] [PubMed]

31. Wu, C.J.; Lian, Y.J.; Zheng, Y.K.; Zhang, H.F.; Chen, Y.; Xie, N.C.; Wang, L.J. Botulinum toxin type A for the treatment of trigeminal neuralgias: Results from a randomized, double-blind, placebo-controlled trial. Cephalgia 2012, 32, 443-450. [CrossRef] [PubMed]

32. Zhang, H.; Lian, Y.; Ma, Y.; Chen, Y.; He, C.; Xie, N.; Wu, C. Two doses of botulinum toxin type A for the treatment of trigeminal neuralgia: Observation of therapeutic effect from a randomized, double-blind, placebo-controlled trial. J. Headache Pain. 2014, 15, 65. [CrossRef] [PubMed]

33. Zuniga, C.; Piedimonte, F.; Diaz, S.; Micheli, F. Acute treatment of trigeminal neuralgia with onabotulinum toxin A. Clin. Neuropharmacol. 2013, 36, 146-150. [CrossRef] [PubMed]

34. Bohluli, B.; Motamedi, M.H.; Bagheri, S.C.; Bayat, M.; Lassemi, E.; Navi, F.; Moharamnejad, N. Use of botulinum toxin A for drug-refractory trigeminal neuralgia: Preliminary report. Oral Surg. Oral Med. Oral Pathol. Oral Radiol. Endod. 2011, 111, 47-50. [CrossRef] [PubMed]

35. Zuniga, C.; Diaz, S.; Piedimonte, F.; Micheli, F. Beneficial effects of botulinum toxin type A in trigeminal neuralgia. Arq. Neuropsiquiatr. 2008, 66, 500-503. [CrossRef] [PubMed]

36. Turk, U.; Ilhan, S.; Alp, R.; Sur, H. Botulinum toxin and intractable trigeminal neuralgia. Clin. Neuropharmacol. 2005, 28, 161-162. [PubMed]

37. Xiao, L.; Mackey, S.; Hui, H.; Xong, D.; Zhang, Q.; Zhang, D. Subcutaneous injection of botulinum toxin A is beneficial in postherpetic neuralgia. Pain Med. 2010, 11, 1827-1833. [CrossRef] [PubMed]

38. Apalla, Z.; Sotiriou, E.; Lallas, A.; Lazaridou, E.; Ioannides, D. Botulinum toxin A in postherpetic neuralgia: A parallel, randomized, double-blind, single-dose, placebo-controlled trial. Clin. J. Pain 2013, 29, 857-864. [CrossRef] [PubMed]

39. Liu, H.T.; Tsai, S.K.; Kao, M.C.; Hu, J.S. Botulinum toxin A relieved neuropathic pain in a case of post-herpetic neuralgia. Pain Med. 2006, 7, 89-91. [CrossRef] [PubMed]

40. Sotiriu, E.; Apalla, Z.; Panagiotidou, D.; Ioannidis, D. Severe post-herpetic neuralgia successfully treated with botulinum toxin A: Three case reports. Acta Derm.-Venereol. 2009, 89, 214-215.

41. Ranoux, D.; Attal, N.; Morain, F.; Bouhassira, D. Botulinum toxin type A induces direct analgesic effects in chronic neuropathic pain. Ann. Neurol. 2008, 64, 274-283. [CrossRef] [PubMed]

42. Layeeque, R.; Hochberg, J.; Siegel, E.; Kunkel, K.; Kepple, J.; Henry-Tillman, R.S.; Dunlap, M.; Seibert, J.; Klimberg, V.S. Botulinum toxin infiltration for pain control after mastectomy and expander reconstruction. Ann. Surg. 2004, 240, 608-613. [CrossRef] [PubMed]

43. Fabregat, G.; Asensio-Samper, J.M.; Palmisani, S.; Villanueva-Pérez, V.L.; De Andrés, J. Subcutaneous botulinum toxin for chronic post-thoracotomy pain. Pain Pract. 2013, 13, 231-234. [CrossRef] [PubMed] 
44. Rostami, R.; Mittal, S.O.; Radmand, R.; Jabbari, B. Incobotulinum toxin-A improves post-surgical and post-radiation pain in cancer patients. Toxins 2016, 8, 22. [CrossRef] [PubMed]

45. Yuan, R.Y.; Sheu, J.J.; Yu, J.M.; Chen, W.T.; Tseng, I.J.; Change, H.H.; Hu, C.J. Botulinum toxin for diabetic neuropathic pain: A randomized double-blind crossover trial. Neurology 2009, 72, 1473-1478. [CrossRef] [PubMed]

46. Ghasemi, M.; Ansari, M.; Basiri, K.; Shaigannejad, V. The effects of intradermal botulinum toxin type A injections on pain symptoms of patients with diabetic neuropathy. J. Res. Med. Sci. 2014, 19, 106-111. [PubMed]

47. Lakhan, S.E.; Velasco, D.N.; Tepper, D. Botulinum toxin-A for painful diabetic neuropathy: A meta-analysis. Pain Med. 2015, 16, 1773-1780. [CrossRef] [PubMed]

48. Kapural, L.; Stillman, M.; Kapural, M.; Mclntyre, P.; Guirgius, M.; Mekhail, N. Botulinum toxin occipital nerve block for the treatment of severe occipital neuralgia: A case series. Pain Pract. 2007, 7, 337-340. [CrossRef] [PubMed]

49. Taylor, M.; Silva, S.; Cottrell, C. Botulinum toxin type A in the treatment of occipital neuralgia: A pilot study. Headache 2008, 48, 1476-1481. [CrossRef] [PubMed]

50. Breuer, B.; Sperber, K.; Wallenstein, S.; Kiprovski, K.; Calapa, A.; Snow, B.; Pappagallo, M. Clinically significant placebo analgesic response in a pilot trial of botulinum B in patients with hand pain and carpel tunnel syndrome. Pain Med. 2006, 7, 16-24. [CrossRef] [PubMed]

51. Tsai, C.P.; Liu, C.Y.; Lin, K.P.; Wnag, K.C. Efficacy of botulinum toxin type A in the relief of carpal tunnel syndrome. Clin. Drug Investig. 2006, 26, 511-515. [CrossRef] [PubMed]

52. Safarpour, D.; Jabbari, B. Botulinum toxin a (Botox) for treatment of proximal myofascial pain in complex regional pain syndrome: Two cases. Pain Med. 2010, 11, 1415-1418. [CrossRef] [PubMed]

53. Safarpour, D.; Salardini, A.; Richardson, D.; Jabbari, B. Botulinum toxin A for treatment of allodynia of complex regional pain syndrome: A pilot study. Pain Med. 2010, 11, 1411-1414. [CrossRef] [PubMed]

54. Carroll, I.; Clark, J.D.; Mackey, S. Sympathetic block with botulinum toxin to treat complex regional pain syndrome. Ann. Neurol. 2009, 65, 348-351. [CrossRef] [PubMed]

55. Argoff, C.E. Botulinum toxin type A treatment of myofascial pain in patients with CRPS Type 1 (reflex sympathetic dystrophy): A pilot study. In Proceedings of the World Pain Congress (IASP) Meeting, Vienna, Austria, 22-27 August 1999.

56. Kharkar, S.; Ambady, P.; Venkatesh, Y.; Schwartzman, R.J. Intramuscular botulinum toxin in complex regional pain syndrome: Case series and literature review. Pain Phys. 2011, 14, 419-424.

57. Wu, H.; Sultana, R.; Taylor, K.B.; Szabo, A. A prospective randomized double-blinded pilot study to examine the effect of botulinum toxin type A injection vs. Lidocaine/Depomedrol injection on residual and phantom limb pain. Clin. J. Pain 2012, 28, 108-112. [CrossRef] [PubMed]

58. Kern, U.; Martin, C.; Scheicher, S.; Muler, H. Long-term treatment of phantom and stump pain with Botulinum toxin type A over 12 months. A first clinical observation. Nervenarzt 2004, 75, 336-340. [CrossRef] [PubMed]

59. Han, Z.A.; Song, D.H.; Oh, H.M.; Chung, M.E. Botulinum toxin type A for neuropathic pain in patients with spinal cord injury. Ann. Neurol. 2016, 79, 569-578. [CrossRef] [PubMed]

60. Li, G.; Lv, C.A.; Tian, L.; Jin, L.J.; Sun, P.; Zhao, W. A randomized controlled trial of botulinum toxin A for treating neuropathic pain in patients with spinal cord injury. Medicine 2017, 96, e6919. [CrossRef] [PubMed]

61. Jabbari, B.; Maher, N.; Difazio, M.P. Botulinum toxin A improved burning pain and allodynia in two patients with spinal cord pathology. Pain Med. 2003, 4, 206-210. [CrossRef] [PubMed]

62. Han, Z.A.; Song, D.H.; Chung, M.E. Effect of subcutaneous injection of botulinum toxin A on spinal cord injury-associated neuropathic pain. Spinal Cord 2014, 52, S5-S6. [CrossRef] [PubMed]

63. Shippen, C.; Bavikatte, G.; Mackarel, D. The benefit of botulinum toxin A in the management of central post stroke pain: A case report. J. Neurol. Stroke 2017, 6, 00218. [CrossRef]

64. Camoes-Barbosa, A.; Neves, A.F. The analgesic effect of abobotulinum and incobotulinum toxins type A in central poststroke pain: Two case reports. PMER 2016, 8, 384-387.

65. Wissel, J.; Ganapathy, V.; Ward, A.B.; Borg, J.; Ertzgaard, P.; Herrmann, C.; Haggstrom, A.; Sakel, M.; Ma, J.; Dimitrova, R.; et al. Onabotulinum toxin A improves pain in patients with post-stroke spasticity: Findings from a randomized, double-blind, placebo-controlled trial. J. Pain Symptom Manag. 2016, 52, 17-26. [CrossRef] [PubMed] 
66. Sławek, J.; Madaliński, M.H.; Maciag-Tymecka, I.; Duzyński, W. Frequency of side effects after botulinum toxin A injections in neurology, rehabilitation and gastroenterology. Pol. Merkur. Lek. 2005, 18, 298-302.

67. Kessler, K.R.; Skutta, M.; Benecke, R. Longterm treatment of cervical dystonia with botulinum toxin A: Efficacy, safety, and antibody frequency. German Dystonia Study Group. J. Neurol. 1999, 246, 265-274. [CrossRef] [PubMed]

68. Greene, P.; Fahn, S.; Diamond, B. Development of resistance to botulinum toxin type A in patients with torticollis. Mov. Disord. 1994, 9, 213-217. [CrossRef] [PubMed]

69. Moon, Y.E.; Choi, J.H.; Park, H.J.; Park, J.H.; Kim, J.H. Ultrasound-guided nerve block with botulinum toxin type A for intractable neuropathic pain. Toxins 2016, 8. [CrossRef] [PubMed]

2017 by the authors. Licensee MDPI, Basel, Switzerland. This article is an open access article distributed under the terms and conditions of the Creative Commons Attribution (CC BY) license (http://creativecommons.org/licenses/by/4.0/). 